\title{
ONLINE COLLABORATIVE WRITING IN ENGLISH AT THE FEDERAL INSTITUTE OF RIO GRANDE DO NORTE: SOME QUANTITATIVE DATA ON STUDENT PARTICIPATION IN INTEGRATED SECONDARY EDUCATION
}

\section{ESCRITA COLABORATIVA ONLINE EM LÍNGUA INGLESA NO INSTITUTO FEDERAL DO RIO GRANDE DO NORTE: ALGUNS DADOS QUANTITATIVOS DA PARTICIPAÇÃO DOS ALUNOS DO ENSINO MÉDIO INTEGRADO}

\author{
Sabrina Guedes Miranda Dantas* \\ Samuel de Carvalho Lima **
}

\begin{abstract}
Online Collaborative Writing (OCW) on Google Docs has been used as an approach to the teaching of English as a foreign language in Brazil. In this article, we present some quantitative data on OCW drawn from a larger pedagogical intervention research related to the participation of 36 students in the Technical Integrated Secondary Education Program in Computing at the Federal Institute of Rio Grande do Norte. Students were divided into seven groups to write collaborative posts for an informative blog over three online sessions on Google Docs. The initial findings are related to frequency, time, and interactions during those sessions. Our conclusion is that time and frequency of students on each session are not related to the amount of interactions, for groups that showed more engagement, in fact, spent less time writing, even though they had an average frequency on the sessions.
\end{abstract}

Keywords: Online Collaborative Writing. English teaching. Integrated Secondary Education ${ }^{1}$.

Resumo: A escrita colaborativa online (ECO) no Google Docs tem sido usada como uma abordagem para o ensino de inglês como língua estrangeira no Brasil. Neste artigo, apresentamos alguns dados quantitativos, provenientes de uma pesquisa de intervenção pedagógica maior, relacionados à participação de 36 alunos do Curso Técnico de Nível Médio Integrado em Informática no Instituto Federal do Rio Grande do Norte. Os alunos foram divididos em sete grupos para escrever, colaborativamente, um post de notícia para blog informativo ao longo de três sessões online. Os achados iniciais estão relacionados à frequência, tempo e interações durante as sessões. Nossa conclusão é que o tempo gasto em cada sessão colaborativa e a frequência dos estudantes não estão relacionadas à quantidade de interações, pois grupos mais engajados tendem a gastar menos tempo, mesmo com uma frequência média durante as sessões.

Palavras-chave: Escrita Colaborativa Online. Ensino de inglês. Ensino Médio Integrado.

\footnotetext{
* Instituto Federal de Educação, Ciência e Tecnologia do Rio Grande do Norte (IFRN) - Campus Apodi. Mestre em Ensino pelo do Programa de Pós-Graduação em Ensino (POSENSINO). Docente de língua inglesa do IFRN. E-mail: sabrina.guedes@ifrn.edu.br

** Instituto Federal de Educação, Ciência e Tecnologia do Rio Grande do Norte (IFRN) - Campus Mossoró. Pós-doutor em Ciências da Educação pela Universidade do Minho (Portugal). Docente de Língua Inglesa do IFRN. E-mail: samuel.lima@ifrn.edu.br

${ }^{1}$ Integrated Secondary Education is a model of curriculum that integrates all the aspects of a human being's life into formal education (arts, humanities, linguistics, technical, science). By doing so, the institution ensures that the students will receive an integral human formation (omnilateral education). Omnilateral education is understood as a way of training "that considers the development of all human dimensions and not just the necessary knowledge for the adaptation of the worker to the dictates of the market" (IFRN, 2012b, p. 53, our translation).
} 


\section{Introduction}

In 2008, Godwin-Jones (2008) presented suggestions on emerging technologies that could foster online writing, due to the advent of Web 2.0. Besides blogs and wikis, the author suggested Google Docs as a future prospect for Online Collaborative Writing (OCW). At that time, Google Docs had just been added to Google Gears (an embedded database) as a tool for online text editing in which documents could be saved, shared and edited online by people who had access to the Google server or the local computer.

A few years later, Wang and Vásquez (2012) organized a literature review with articles published from 2005 to 2009, in which they presented the types of Web 2.0 technologies mostly used as objects of investigation in second language learning. Among the 43 articles analyzed, blogs and wikis led by far the empirical investigations on L2 learning, and only one research used Google Docs as the object of investigation.

In 2018, Godwin-Jones updated his first review of second language writing. Whilst in 2008 the future strands were enabling, documenting and assessing online collaborative writing, in 2018 the author mentioned the need to prepare students for life by motivating them through the use of strategies that allow for more and better writing, collaborative writing, multimodal writing; and by using automated writing evaluations and corrective feedback.

This scenario has changed over the past years, because the "widespread availability of technology-enhanced writing platforms, such as wikis, blogs or Google Docs, has expanded the range, scope, and pattern of collaboration even more dramatically" (YIM; WARSCHAUER, 2017, p. 146), especially regarding the use of Google Docs as a technology that fosters collaborative writing.

Bringing these prospects to our reality, the discussion about the potential and limitations of using digital technologies to teach and learn a foreign language is not a novel one in Brazil. Almost 20 years ago, Braga and Costa (2012) ${ }^{2}$ explained, through experiences, that computers connected to the internet could be used as teaching tools to enhance teacher autonomy in relation to the textbook.

The authors stressed the potential of the internet for creating and accessing authentic materials available online. However, they also make it clear that these potentialities could only be achieved through teacher training so that teachers could become familiar with the possibilities of electronic literacy.

Nearly two decades later ${ }^{3}$, Menezes (2019) demonstrates the need to consider the late arrival of computers in the context of Brazilian schools. The author stresses the need for new ways to learn, teach and interact and makes predictions for the future. Among the predictions, we would like to highlight two of them: 1) broadband internet with extensive free access and 2) inclusion of the debate about the integration of digital technologies in teaching in teacher training.

These prognoses seem to have been granted emergency status against the backdrop of the ongoing novel coronavirus pandemic, as schools shifted to remote instruction in order to promote the social distancing necessary for preserving human life. Therefore, we believe that sharing experiences about possibilities related to using

\footnotetext{
2 This article was written in 2000 and retrieved for publication in 2012. In 2000, Braga and Costa (2012) affirm the need for teaching training to use technologies. 20 years later, Menezes (2019) foresees teacher's training for the future, as something still to be done.

${ }^{3}$ We are considering the date Braga and Costa's article was written.
} 
computers connected to the internet to promote interactions between teachers and students through online collaborative writing can contribute to the necessary dialogue pointed out by the aforementioned studies.

In this sense, we present Online Collaborative Writing (OCW) on Google Docs as a possibility for all language teachers, since this approach has been used in the teaching of Portuguese as a first language (L1) (RIBEIRO; JESUS, 2019; AZZARI; CUSTÓDIO, 2013), of English as a foreign language in Brazil (EFL) (LEANDRO; WEISSHEIMER, 2017; LEANDRO; WEISSHEIMER; COOPER, 2013) and in a number of other countries (CHO, 2017; STROBL, 2014; KESSLER; BIKOWSKI; BOGGS, 2012).

Despite these studies, Yim and Warschauer (2017) point out that there is still a methodological gap among the investigations on OCW since some of the researches use a qualitative approach to small groups of students ${ }^{4}$. For instance, the authors claim that, if applied to larger groups or for longer periods of time, such an approach could lead to insufficient understandings of collaborative writing in regards to the quality-quantity relationship and of how this collaboration affects the task outcomes or the perceptions of students in the process

The authors also suggest approaches that can provide more quantifiable data "to better understand the characteristics of collaborative scaffolding and mediations" (YIM; WARSCHAUER 2017, p. 147). For that reason, in this research article we present some quantitative data on OCW related to the participation of 36 students in the Technical Integrated Secondary Education Program in Computing. The data emerged from a larger investigation on Online Collaborative Writing on Google Docs at a Federal Institute in Rio Grande do Norte. This investigation thus took place in the scope of some researches that seek to elucidate educational phenomena in order to foster language learning in Integrated Secondary Education in public schools (LIMA; LIMA; AMARAL, 2020; PINTO; LIMA, 2020; GUERRA; LIMA, 2019; LIMA; ALVES, 2019; SILVA; LIMA, 2019; SOARES; LIMA, 2019; REIS; LIMA, 2018).

As for organizational purposes, we first summarize the definition of Collaborative Writing and its pedagogical possibilities in an online cloud-based system tool, such as Google Docs. Then, we present the methodology used in this research, the collected data and the discussions. Lastly, we point out the pedagogical implications of such an approach for the students in Integrated Secondary Education programs at the Federal Institute of Rio Grande do Norte 5 .

\section{Theoretical Framework.}

Collaborative Writing (CW) can be placed in the wider scope of Collaborative Learning (CL) as "an umbrella term for a variety of educational approaches involving joint intellectual effort by students, or students and teachers together" (SMITH;

\footnotetext{
${ }^{4}$ The studies mentioned by Yim and Warschauer (2017) consisted of groups of 4 or 9 students. The research questions were related to changes in the quantity of input and the quality of the outcome or to patterns of group interaction.

5 The Federal Institutions are schools maintained by the federal government that offers technical education integrated to regular High School or not, as well as undergraduate, graduate, and postgraduate courses all over Brazil.
} 
MACGREGOR, 1992, p. 11). Multiple definitions have been used to describe CW, as demonstrated below.

Smith and McGregor (1992) named their approach "peer writing". This approach "involves students working in small groups at every stage of the writing process" (SMITH; MACGREGOR, 1992, p. 11). Even though the authors did not use the term Collaborative Writing, their definition approximates to the writings of Allen, et al. (1987), who assert that "collaborators producing a shared document, engaging in substantive interaction about that document, and sharing decision-making power and responsibility for it" (ALLEN et al., 1987, p. 70).

Another definition that summarizes Collaborative Writing is furnished by Fung (2006, p. 21): "two or more people sharing responsibility for producing a single document through mutual interactions, shared expertise, and joint decision-making throughout the writing process".

The aspects shared by the above definitions can be seen on Figure 1, in which such terms as "writing process", "responsibility" and "sharing" stand out, thereby capturing the essence of this approach.

Figure 1 - Word cloud on the definition for collaborative writing

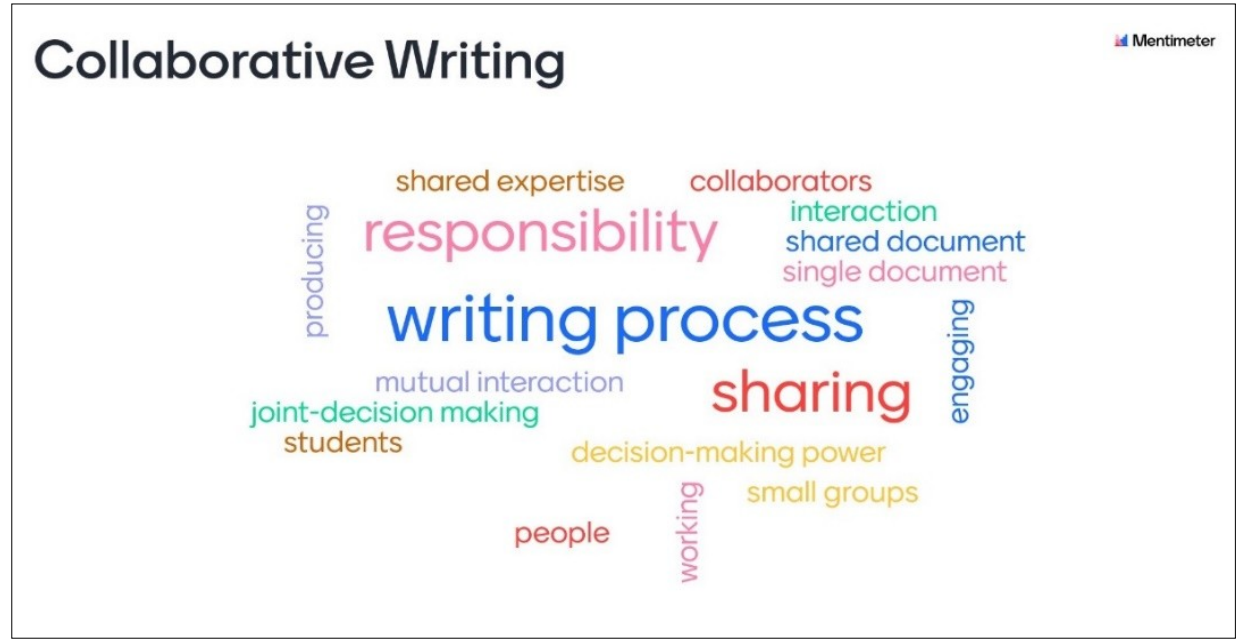

Source: created by the authors.

According to Yim and Warschauer (2017, p. 146), OCW can be a helpful asset to second language (L2), and, in our context, to the teaching and learning of English as a foreign language (FL) since it creates "communicative opportunities to practice English in a non-threatening and engaging environment with little restriction on time and space".

In addition, the authors likewise acknowledge that the language learning benefits (e.g. improvement of quality and fluency in writing, audience awareness), along with student engagement in practices that promote the enhancement of $21^{\text {st- }}$ century literacies which are currently required, are considered important as research study objects (cf. YIM; WARSCHAUER, 2017).

Furthermore, the increased interest in OCW research and the widespread use of online sharing tools such as Google Docs also has to do with the application of sociocultural theories as theoretical frameworks (cf. GODWIN-JONES, 2018; YIM; WARSCHAUER, 2017). Drawing from these writings, Yim and Warschauer (2017) point out three major research strands on collaborative writing: processes, outcomes, and students' perceptions. 
As for the processes in OCW, the research is divided into two groups: patterns and phases of collaboration. Collaboration patterns investigate the ways students interact. In the work of Ribeiro and Jesus (cf. RIBEIRO; JESUS, 2019), for instance, the taxonomy put forward by Lowry, Curtis and Lowry (2004) is used to investigate how students interacted on Google Docs and, by observation, defined the incidence of these patterns in the writing process. At the end of the research, the authors suggest a reorganization of the participants' roles in relation to the theory proposed by Lowry, Curtis, and Lowry (2004) (cf. LOWRY; CURTIS; LOWRY, 2004).

The collaboration phases concentrate on the development of processes and subprocesses during writing. For example, Bento (2011) observed the processes performed by students during pre-writing (brainstorming), writing (comments leading to new versions of texts) and post-writing (text editing) (cf. BENTO, 2011).

In regards to products, research of a more quantitative nature takes on a more prominent role in this analysis, as they take the product into account by making grammatical and lexical analyses. For example, Leandro and Weissheimer (2017) used a mixed method of research in which they investigated the relation of OCW to the improvement of grammatical accuracy and lexical density (e.g. more lexical substitutions) among students' productions as L2 learners of English. As for the results, the quantitative data indicated that students focused more on the process, rather than the product, and the texts showed higher lexical density (cf. LEANDRO; WEISSHEIMER, 2017).

Secondly, they collected students' perceptions on the OCW process, and the genre (flash fiction) was chosen by the teachers. Concerning the process, students regarded as positive the opportunity of revision and edition throughout the process; however revision also caused conflict, since some of the changes made were not discussed by the entire group. As for the genre, students engaged in writing a flash fiction narrative and considered this task to be challenging in a positive sense, even though the word "challenge" was also used to express a negative feeling towards the limitation of words they had (cf. LEANDRO; WEISSHEIMER, 2017).

In spite of employing a quantitative method, Leandro and Weissheimer are included in the scarce group of researchers that investigates the collaborative outcomes in accordance with the review of Yim and Warschauer (2017). The authors suggest "the need to implement more objective measurements of writers' collaborative behaviors" (YIM; WARSCHAUER, 2017, p. 151).

All the works concerning OCW cited in this article used Google Docs as an online tool to foster collaboration, interaction, negotiation and learning of a second language. Google Docs is a tool included in a package provided by Google, along with other productivity tools, which can be used with a personal email or through accounts linked to institutions.

Since Google Docs is a tool classified as a cloud-based writing system that allows users to work in groups, the interactions on the platform can be either synchronous or asynchronous. Asynchronously, authors can leave comments directly beside the texts with the "Add a comment" tool. In synchronous interactions, authors can communicate via the available chat tool. The History Version makes it possible to track the several versions of a text, by date and time of modification. All changes and interactions are recorded under the names of the editing authors, with the proviso that they are logged 
in; if not, the changes are registered anonymously (STROBL, 2014; GODWIN-JONES, 2018; YIM; WARSCHAUER, 2017; YEH, 2014).

Google Docs was chosen for the present research because of its affordances in the field of OCW, with a view to investigating their processes and outcomes in collaborative written productions.

\section{Method}

This Pedagogical Intervention (cf. DAMIANI, 2013) took place under the auspices of the course titled "English II", which corresponds to 90 contact hours distributed throughout the school year. The research group was composed of second year students in the Integrated Secondary Education Program in Computer Science.

English II aims to provide a deepening of the contents learned in the previous course (English I) through the exposure of students to a variety of oral and written texts through the teaching of socio-communicative functions.

This research was submitted to an Ethics Committee which issued a favorable opinion under number 3.637.826 - CAAE 20284719.5.0000.5294. After the approval, formal consent was obtained from students and their legal guardians, since the ages of the group varied from 15 to 18 years old. Thus, 36 pupils participated in this investigation and they were divided into 7 groups six groups of five students and one group of six students).

The groupings were assigned based on the average grades of the students from the first semester of the year ${ }^{6}$. This decision was made to guarantee that each group comprised students at different levels of proficiency. After assigning the groups, they were encouraged to create their own group names, according to Figure 2.

Figure 2- Group distribution

\begin{tabular}{|c|c|c|c|}
\hline G1 - ECO PEACE & G2 - NAMELESS & $\begin{array}{c}\text { G3 - NORTHEAST } \\
\text { GANG }\end{array}$ & $\begin{array}{c}\text { G4 - GAROTOS } \\
\text { DE PROGRAMA }\end{array}$ \\
\hline S2 & S6 & S11 & S12 \\
S23 & S24 & S25 & S26 \\
S31 & S33 & S36 & S37 \\
S7 & S8 & S10 & S32 \\
S20 & S21 & S29 & \\
S18 & G6 - AMADOS & G7 - NORTHEAST BEACH DEFENDERS \\
\hline G5 - SERHUMAN & S17 & \multicolumn{2}{|c|}{ S22 } \\
S15 & S28 350 \\
S27 & S3 & S5 \\
S1 & S16 & S19 \\
S14 & S35 & \multicolumn{2}{|c}{ S4 } \\
S34 & \multicolumn{2}{|c|}{} \\
\hline
\end{tabular}

Source: created by the authors.

\footnotetext{
${ }^{6}$ Standardized or any kind of proficiency tests were not carried out during the research. We acknowledge the different proficiency levels by considering the different backgrounds of the students and their performances based only on their grades from the first semester of 2019.
} 
The intervention was carried out from October through December of 2019; however, the data presented in this article was collected during the online meetings that we called Collaborative Sessions (CS). All groups gathered for the 3 CSs in November and, as researchers, we were present in all CSs, overseeing students' progress, being available to answer their questions, taking notes and observing their engagement in the chat.

Students in an English II class have already had at least one year of English as a Foreign Language studies (EFL), from which one can surmise a working knowledge of basic Simple Present structures and the vocabulary usually related to this tense. In English II, the table of verbal tenses include the Simple Past, the Present Continuous and the Simple Future.

Seeing as the contents are organized by socio-communicative functions, teachers are directed to use an approach that tends to be the communicative model of language teaching. However, there is no obligation regarding the adoption of a single method or approach to be used by teachers. Among the procedures suggested for use in class - at the discretion of the teacher - are lectures, oral or written activities, projects using text genres of different natures (songs, videos, news, poems, abstracts, résumés), internet research, vocabulary worksheets, and individual and group activities (IFRNb, 2012).

Thus, the students were asked to write a collaborative news $\operatorname{article}^{7}$ on Google Docs, to be posted on an informational blog, about the oil spill that washed up over thousands of kilometers of Brazil's Northeast coastline in 2019. At the end of the three $\mathrm{CSs}$, each group had produced a final version of their respective texts, as required for completion of the task.

The main objective of the text was to inform high school students from other parts of the world about the environmental disaster happening at that time. We used a picture as a stimulus (Fig. 3) and the students were challenged to write 3 or 4 paragraphs of a news article, whose characteristics were presented to them in class. Aware of the main task, each CS focused on subtasks that were designed to plan (CS1), write (CS2) and review (CS3) the text in progress.

Figure 3 - Picture used as stimulus

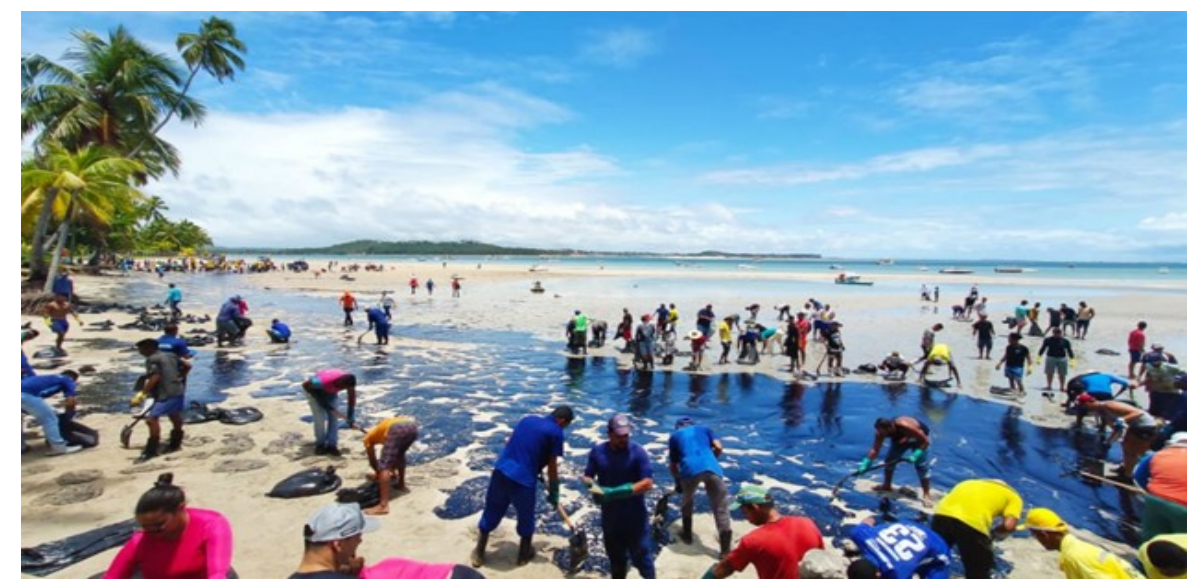

\footnotetext{
${ }^{7}$ Before the three Collaborative Sessions from which the data was collected, two face-to-face meetings happened. The first one to present Google Docs and its tools, and the second one to present the features of a news article in the format of a post for an informational blog. This type of blog is the most popular in the municipalities from which the students come.
} 
Source: Bruno Campos/JC Imagem ${ }^{8}$

To present the results in this article, we followed these procedures in every CS. First, we counted the number of students logged in per session and divided it by three to obtain the average number of students per session. We also recorded the screens of our computers using a feature available on Microsoft PowerPoint to measure the time spent on each session. Then we copied the transcripts of all chat interactions and saved them in a Microsoft Word file, since the chat tool is available only when two or more participants are working on the text.

In order to count the interactions, we numbered all the text insertions in the chat sessions. The entries were listed considering all the text input by a participant (S1, S2, and so on) until another member typed another sentence. Per the purpose of this article, the content of the interactions was not analyzed. The entries were counted as shown in the following excerpt, extracted from CS1 of the Northeast Gang group.

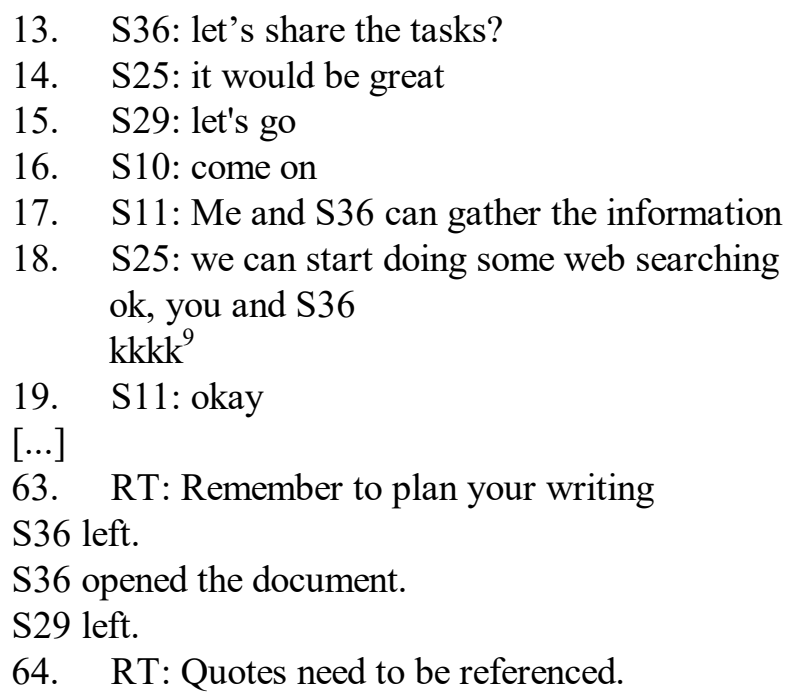

As seen above, entry 18 ends when S11 inserts another comment in response to S25 to make sure they negotiated meaning clearly; that is to say, when collaborating, the number of interactions increases. After entry 63, examples of automatic notifications sent by Google Docs can be seen. These were not counted as entries for the purposes of this research. By counting the entries of each participant in each group, we aimed to showcase the interactive behavior of the groups during an online activity: after all, interaction is seen as a fundamental characteristic for collaboration.

\section{Results and discussion}

After observing the Collaborative Sessions (CS) and following the methodological procedures, we present herein the collection of data and the assumptions drawn from analyzing it. Table 1 below evinces student attendance during the online collaborative sessions.

\footnotetext{
${ }^{8}$ This picture is available at: https://tvjornal.ne10.uol.com.br/noticias/2019/10/21/manchas-de-oleo-vejaas-tres-teorias-sobre-o-desastre-ambiental-nas-praias-do-nordeste-178188. Accessed on May 29 2020. ${ }^{9}$ An onomatopoeia that represents laugh. In English, it corresponds to LOL.
} 
Table 1 - Student attendance per collaborative session

\begin{tabular}{l|c|c|c|c}
\hline & CS1 & CS2 & CS3 & $\begin{array}{c}\text { AVERAGE } \\
\text { ST/CS }\end{array}$ \\
\hline ECO PEACE & 6 & 5 & 5 & 5,3 \\
\hline NAMELESS & 5 & 4 & 0 & 3,0 \\
\hline NORTHEAST GANG & 5 & 4 & 2 & 3,6 \\
\hline GAROTOS DE PROGRAMA & 4 & 4 & 3 & 3,6 \\
\hline SERHUMAN & 4 & 2 & 2 & 2,6 \\
\hline AMADOS & 5 & 3 & 2 & 3,3 \\
NORTHEAST BEACH & 1 & 3 & 2 & 2,0 \\
\hline
\end{tabular}

Source: created by the authors.

Each of the columns in Tab. 1 lists the number of participants in per CS. The average student attendance per group is presented on the far-right column, according to which "Eco Peace" was the group with the highest average, with "Northeast Beach Defenders" exhibiting the lowest average attendance.

The average of each student's attendance throughout the CS was 3,34 students/CS. According to Tab. 1, it can be concluded that participation decreased in almost all the groups over the different Sessions. The only group that demonstrated a different pattern from the others was "Northeast Beach Defenders", with only one student participating in CS1, making an inverse trajectory in relation to the other groups between CS1 and CS2, going into decline from CS2 to CS3.

The group that showed the best performance with regards to attendance was "Eco Peace", which saw the participation of all of its members in CS1, with the absence of a single student in the following Sessions. Even though "Eco Peace" was the largest group, it was the only group that maintained the pattern of only one absence per session.

The group that showed the lowest frequency among its participants was "Northeast Beach Defenders". This pattern did not implicate on the conclusion of the task; however, the sense of collaboration in CS1, for instance, was not possible to be achieved, since the student did the planning of text by himself/herself. "Nameless" was the only group that did not finish the task of writing a news article, because the group did not attend CS3.

CS1 was the session that had the highest level of attendance by the students in relation to the others. In this Session, students were asked to plan the writing of the text. Considering the essence of pre-writing activities such as brainstorming in which students pool their ideas for a text and organize an outline, it is possible to assume that in those activities, in an online collaborative writing environment, the participation and interaction of students would be higher. This hypothesis was confirmed since the Collaborative Session dedicated to planning had the highest frequency in almost all groups.

In addition to students' attendance, the duration of each CS was also accounted for in minutes. Since the online meetings were complementary (extracurricular) hours to the course, the Sessions considered the minimum and maximum time of the weekly English classes of the researched institution (45-135 minutes per week). Thus, we present Table 2 with the time allotted to each CS by group. 
Table 2 - Time spent in the Collaborative Sessions in minutes

\begin{tabular}{l|c|c|c|c}
\hline & CS1 & CS2 & CS3 & $\begin{array}{c}\text { TOTAL PER } \\
\text { GROUP }\end{array}$ \\
\hline ECO PEACE & 72 & 77 & 61 & 210 \\
\hline NAMELESS & 88 & 48 & 0 & 136 \\
\hline NORTHEAST GANG & 97 & 80 & 115 & 292 \\
\hline GAROTOS DE PROGRAMA & 82 & 65 & 49 & 195 \\
\hline SERHUMAN & 93 & 122 & 137 & 352 \\
\hline AMADOS & 77 & 34 & 38 & 149 \\
\hline NORTHEAST BEACH & 34 & 87 & 85 & 206 \\
\hline \multicolumn{1}{c|}{ TOTAL TIME PER SESSION } & 553 & 513 & 483 & \\
\hline
\end{tabular}

Source: created by the authors.

Although some Sessions lasted less than the minimum time and others exceeded the maximum time, in general, the duration served the purpose of allowing students more time on English and OCW complementary activities, the average duration of each CS was 73 minutes. According to Tab. 2, the group which spent more time on online collaboration was "Serhuman", and the opposite held true for "Nameless".

We observed that in longer sessions, such as those of the "Serhuman" group, interactions in the chat were limited to clarifications and division of tasks. The students did not engage in any discussions about the text or the tasks, despite there having been time apportionments dedicated to the CS.

The amount of time invested in collaboration efforts did not represent substantial interactions or completion of the tasks. This could only be assumed by the observations made during the CS. The groups that spent less time were not necessarily the ones with less interactions or that did not finish the tasks assigned for the day. The groups showed to be highly efficient in regards to the time for completion of the task by using the tools in an adequate way.

The "Amados" group was the group that invested the lowest amount of time on the Sessions ${ }^{10}$; however, the engagement and collaboration in the chat allowed them to achieve the early completion of some tasks from one Session to another.

One of the disadvantages noted by Leandro and Weissheimer (2013) was that students showed discomfort due to edits in the text that were neither explained, nor discussed in online collaborations. This behavior could have been prevented if the students had used the communication tools available, (e.g. the chat tool) for explaining or negotiating those changes in the text. Using the chat in an efficient way could lead to less time and maybe less problems involving collaboration.

In face-to-face collaboration, Storch (2005) considered the time spent on each phase (planning, writing, revision) of writing among pair work. The author concluded that the dyads spent most of the time pooling ideas. Generating ideas is commonly attached to the planning of a text; nevertheless, she observed that students spent more time on writing, rather than on planning or revision.

This shows that students were pooling ideas during the process, rather than only in the planning phase. The same thing happened in the revision phase, since the author noted that few students engaged in revision despite the possibility of dedicating time to

\footnotetext{
${ }^{10}$ We affirm that because the Nameless group did not meet for the last CS, being the only one that did not complete the writing of the text.
} 
revise the text. These findings point to the fact that students pay the most attention to ideas and then language.

Our results show a different behavior when time is the only variable under observation, for students spent more time in CS1, which was dedicated to planning, and not in the other Sessions. This does not mean that they stopped generating ideas, did not write or revise the text. However, from observing the CS, we can conclude that the groups spent more time on planning because they were also writing during the planning process.

As the attendance of students and the time spent in each CS decreased over the three online meetings, the number of interactions also followed the same pattern, as shown in Table 3.

Table 3 - Amount of interactions per collaborative session

\begin{tabular}{l|c|c|c|c}
\hline & CS1 & CS2 & CS3 & $\begin{array}{c}\text { TOTAL/ } \\
\text { GROUP }\end{array}$ \\
\hline ECO PEACE & 51 & 29 & 16 & 96 \\
\hline NAMELESS & 34 & 28 & 0 & 62 \\
\hline NORTHEAST GANG & 80 & 7 & 25 & 112 \\
\hline GAROTOS DE PROGRAMA & 60 & 20 & 15 & 95 \\
\hline SERHUMAN & 44 & 30 & 28 & 102 \\
\hline $\begin{array}{l}\text { AMADOS } \\
\text { DERTHEAST BEACH }\end{array}$ & 117 & 107 & 20 & 244 \\
\hline $\begin{array}{r}\text { TOTAL OF INTERACTIONS/ } \\
\text { SESSION }\end{array}$ & 398 & 59 & 33 & 104 \\
\hline
\end{tabular}

Source: created by the authors.

According to Tab. 3, with each $\mathrm{CS}$, the number of chat entries decreased progressively in almost all groups, apart from two: "Northeast Gang" and "Northeast Beach Defenders". The first group showed a decrease in interactions from CS1 to CS2, and a resumption of growth from CS2 to CS3. Exceptional behavior can be justified by reasons that go beyond counting interactions

"Northeast Gang" CS2 was marked by problems with entering and leaving the document writing session. This behavior may have been caused by the fact that the students were at the institution doing the work, as could be observed during the CS.

In CS3, participating students did not report any problems and were able to complete the task with more interaction in relation to CS2, even though there were only two participants collaborating. When considering the problems of access to the document, availability of computers and internet connection, to the participation and quantity of interactions, we can conclude that the smaller groups, with access to better social and work conditions, tended to perform tasks more fluidly.

The "Northeast Beach Defenders" group demonstrated an increase in the amount of interactions from CS1 to CS2 and then a decrease from CS2 to CS3. A possible justification for this behavior may be related to the number of students interacting in all CS.

In CS1, only one student was present, and the interactions happened, even so, between the student and the researcher-teacher. In CS2, three students were present, interacting efficiently in the writing of the text, and the same behavior happened at CS3, which had the participation of two students. By observing this behavior, it is possible to 
conclude that the interaction is related to the students' engagement in carrying out the activity and not necessarily the number of members present in the CS.

Interaction is the fundamental characteristic for collaborative activities to happen, from which other characteristics are possible. Without interaction, there is no room for conflict, negotiation or sharing of expertise, examples of the defining characteristics of Collaborative Writing, according to Fung (2010). A greater number of interactions could allow a higher incidence of negotiation, conflict, sharing of expertise, or use of L2.

Yim et al. (2017) used a mixed-method approach to investigate the relation of collaborative features and quantity and quality of the text in synchronous collaboration. One of the conclusions was that document length was not related to quantity of authors, but to the level of participation.

Although, we did not compare the numbers we found in our research to the outcomes of the process, our initial findings could lead to the same conclusions for larger groups, which did not necessarily mean more interactions. For example, the group that showed more interactions ("Amados" $=244$ entries) was on average of frequency ("Amados" = 3,3 ST/CS). On the other hand, the group that had the highest average of frequency ("Eco Peace" = 5,3 ST/CS) showed one of the lowest totals of interactions ("Eco Peace" = 96 entries).

These initial findings agree with the perception that Yim and Warschauer (2017, p. 152) pointed out as the need to use "alternative sources of data for triangulating the qualitative evidence typically seen in collaborative writing research".

\section{Final thoughts}

Online Collaborative Writing (OCW) has shown its prominent value in language teaching and learning, as well as in research. These prospects also benefit from the advancement of cloud-based writing systems, such as Google Docs, which are tools that can help teachers, students, and researchers when more investigations are being carried out to keep up with them.

Research shows that there are many different investigation approaches to OCW. However, quantitative methods are still in development, especially when it comes to comparing the quantity of collaboration and quality of the written texts.

The findings presented in this article are preliminary and are part of a larger study. Our conclusion was that the time spent in each CS and student attendance were not related to the amount of interactions for groups that were highly engaged; in fact, spent less time and showed average attendance over the sessions.

We hope that the data presented so far will help future research and other conclusions, notably because of the context and the subjects of this investigation: students in Integrated Secondary Education programs at the Federal Institute of Education, Science and Technology of Rio Grande do Norte.

\section{References}

ALLEN, N. et al. What experienced collaborators say about collaborative writing. Iowa State Journal of Business and Technical Communication, [s.1.], v. 1, n. 2, p.70-90, set. 1987. SAGE Publications. DOI: http://dx.doi.org/10.1177/105065198700100206. 
AZZARI, E. F.; CUSTÓDIO, M. A. Fanfics, google docs... a produção colaborativa. In: ROXANE, R. (Org.). Escol@ Conectada: os multiletramentos e as TICs. São Paulo: Parábola, 2013, p. 73-92.

BENTO, F. F. A escrita colaborativa no ambiente wiki: uma experiência de ensino/aprendizagem de língua inglesa. Fortaleza, 2011. 221p. Dissertação (Curso de Mestrado em Linguística Aplicada) - Universidade Estadual do Ceará, Fortaleza, 2011. Disponível em: http://www.uece.br/posla/dmdocuments/franciclefortalezabento.pdf Acesso em: 19 jun. 2020.

BRAGA, D. B.; COSTA, L. A. O computador como instrumento e meio para o ensino/aprendizagem de línguas. Trabalhos em Linguística Aplicada, Campinas-SP, v. 36, n. 1, 6 jul. 2012, p. 61-79. Disponível em: https://periodicos.sbu.unicamp.br/ojs/index.php/tla/article/view/8639314. Acesso em 21 jul. 2020.

$\mathrm{CHO}, \mathrm{H}$. Synchronous web-based collaborative writing: factors mediating interaction among second-language writers. Journal of Second Language Writing, [s.1.], v. 36, n. 2, p. 37-51, jun. 2017. Elsevier BV. DOI: https://doi.org/10.1016/j.jslw.2017.05.013. Disponível em: https://www.sciencedirect.com/science/article/abs/pii/S1060374317301741?via\%3Dihub. Acesso em: 18 jun. 2020.

DAMIANI, M. F. et al. Discutindo pesquisas do tipo intervenção pedagógica. Cadernos de Educação, Pelotas, n.45, v. 2, p. 57-67, maio/agosto 2013. DOI: http://dx.doi.org/10.15210/caduc.v0i45.3822. Disponível em: https://periodicos.ufpel.edu.br/ojs2/index.php/caduc/article/view/3822. Acesso em: 18 jun. 2020.

DANTAS, S. G. M.; LIMA, S. de C. A escrita colaborativa no Google Docs: uma proposta de ensino do gênero textual factual recount no ensino técnico de nível médio integrado. Diálogo das Letras, v. 8, p. 157-176, 2019. DOI: http://dx.doi.org/10.22297/dl.v8i3.4129. Disponível em: http://natal.uern.br/periodicos/index.php/DDL/article/view/526. Acesso em: 20 jun. 2020.

FUNG, Y. M. The Nature and Dynamics of Collaborative Writing in a Malaysian Tertiary ESL setting. New Zealand, 2006. 264f. Tese (Curso de Doutorado em Filosofia em Linguística Aplicada,) - Massey University.

FUNG, Y. M. Collaborative Writing Features. Relc Journal, [s.1.], v. 41, n. 1, p.18-30, abr. 2010. DOI: 10.1177/0033688210362610. Disponível em: https://www.researchgate.net/publication/249769114_Collaborative_Writing_Features\#: $\sim:$ text $=$ The $\% 20$ defining $\% 20$ features $\% 20$ are $\% 20$ mutual,class $\% 20$ to $\% 20$ illustrate $\% 20$ the $\% 20$ features. Acesso em: 18 jun. 2020. 
GODWIN-JONES, R. Emerging technologies web-writing 2.0: enabling, documenting, and assessing writing online. Language Learning \& Technology, Hawaii, v. 12, n. 2, p. 7-13, jun. 2008. Disponível em: https://scholarspace.manoa.hawaii.edu/bitstream/10125/44138/1/12_02_emerging.pdf. Acesso em: 18 jun. 2020.

GODWIN-JONES, R. Second language writing online: an update. Language Learning \& Technology, Hawaii, v. 22, n. 1, p.1-15, fev. 2018. Disponível em: https://scholarspace.manoa.hawaii.edu/bitstream/10125/44574/1/22_01_godwinjones.pdf. Acesso em: 18 jun. 2020.

GUERRA, W. T.; LIMA, S. de C. An ESP Teaching Proposal for Oil and Gas Vocational Courses. International Journal of Language \& Linguistics, v. 6, n. 4, p. 8793, 2019. DOI: http://dx.doi.org/10.30845/ijll.v6n4p10. Disponível em: http://www.ijllnet.com/journals/Vol_6_No_4_December_2019/10.pdf. Acesso em: 20 jun. 2020.

IFRNa. Projeto pedagógico do Curso técnico de nível médio em informática, na forma integrada e presencial. Natal: IFRN, 2012.

IFRNb. Projeto político-pedagógico do IFRN: uma construção coletiva: documento base. Natal: IFRN Editora, 2012.

KESSLER, G.; BIKOWSKI, D.; BOGGS, J. Collaborative writing among second language learners in academic web-based projects. Language Learning \& Technology, Hawaii, v. 16, n. 1, p. 91-109, fev. 2012. Disponível em: https://scholarspace.manoa.hawaii.edu/bitstream/10125/44276/1/16_01_kesslerbikowski boggs.pdf. Acesso em: 18 jun. 2020.

LEANDRO, C. D.; WEISSHEIMER, J. Escrita colaborativa de flash fiction e aprendizagem de Inglês como L2: o desenvolvimento da acurácia gramatical e densidade lexical. RAÍDO (ONLINE), v. 11, n. 27, p. 323-337, jun. 2017. DOI: 10.30612/raido.v11i27.5658 Disponível em: http://ojs.ufgd.edu.br/index.php/Raido/article/view/5658. Acesso em: 18 jun. 2020.

LEANDRO, D. C.; WEISSHEIMER, J.; COOPER, J. S. Escrita colaborativa em inglês: produção online e presencial em contexto universitário. Hipertextus Revista Digital, [s.1.], v.10, n. 1, p. 1-18, jul. 2013; ISSN:1981-6081. Disponível em: http:/www.hipertextus.net/volume10/04-Hipertextus-Vol10-Diego-Cesar-

Lendro_Janaina-Weissheimer\&Jennifer-Sarah-Cooper.pdf. Acesso em: 18 jun. 2020.

LIMA, S. de C; ALVES, L. M. Relações entre tecnologias digitais e livro didático no ensino de espanhol: promovendo o letramento digital. Revista Leia Escola, [s.1.], v. 19, n. 1, p. 170-180, 2019. DOI: https://doi.org/10.35572/rle.v19i1.1318. Disponível em: http://revistas.ufcg.edu.br/ch/index.php/Leia/article/view/1318. Acesso em: 20 jun. 2020. 
LIMA, S. C.; LIMA, S. de C.; AMARAL, J. A. Ensino interdisciplinar da escrita de resenhas na educação profissional. Horizontes, [s.1.], v. 38, n. 1, p. 1-13, 2020. DOI: https://doi.org/10.24933/horizontes.v38i1.875. Disponível em: https://revistahorizontes.usf.edu.br/horizontes/article/view/875. Acesso em: 20 jun. 2020.

LOWRY, P.; CURTIS, A.; LOWRY, M. Building a taxonomy and nomenclature of collaborative writing to improve interdisciplinar research and practice. Journal of Business Communication, Washington, v. 41, n. 1, p. 66-99, 2004. Disponível em: https://journals.sagepub.com/doi/abs/10.1177/0021943603259363. Acesso em: 16 jun. 2020.

MENEZES, V. Tecnologias digitais no ensino de línguas: passado, presente e futuro. Revista da ABRALIN, [s.1.], v. 18, n. 1, p. 2-26, ago. 2019. DOI: https://doi.org/10.25189/rabralin.v18i1. Disponível em: https://revista.abralin.org/index.php/abralin/article/view/1323. Acesso em: 24 jul. 2020.

PINTO, M. M. D. da S.; LIMA, S. de C. O ensino do relatório de aula prática na educação profissional: os efeitos de uma intervenção pedagógica na escrita de jovens e adultos. Fólio - Revista de Letras, Vitória da Conquista - BA, v. 11, n. 2, p. 245-266, jan. 2020. ISSN 2176-4182. https://doi.org/10.22481/folio.v11i2.5528. Disponível em: http://periodicos2.uesb.br/index.php/folio/article/view/5528. Acesso em: 20 jun. 2020.

REIS, A. R. S.; LIMA, S. de C. Uma proposta de ensino complementar para os multiletramentos na Educação Profissional. Intersecções. Revista de Estudos sobre Práticas Discursivas e Textuais, v. 11, n. 26, p. 284-299, 2018. Disponível em: https://revistas.anchieta.br/index.php/RevistaInterseccoes/article/view/1382. Acesso em: 20 jun. 2020.

RIBEIRO, A. E.; JESUS, L. M. de. Produção de fanfictions e escrita colaborativa: uma proposta de adaptação para a sala de aula. SCRIPTA, PUCMG, v. 23, n. 48, p. 93-108, out. 2019. DOI: https://doi.org/10.5752/P.2358-3428.2019v23n48p93-108. Disponível em: http://periodicos.pucminas.br/index.php/scripta/article/view/19761. Acesso em: 18 jun. 2020.

SILVA, G. M.; LIMA, S. C. O ensino-aprendizagem da entrevista de emprego em língua inglesa em curso técnico de nível médio. Revista Polyphonía, v. 30, n. 1, p. 56-67, 30 ago. 2019. DOI: https://doi.org/10.5216/rp.v30i1.60191. Disponível em: https://www.revistas.ufg.br/sv/article/view/60191. Acesso em: 20 jun. 2020.

SMITH, B. L.; MACGREGOR, J. T. What is Collaborative Learning? In: GOODSELL, A. et al. Collaborative Learning: a sourcebook for Higher Education. [s.1.]: National Center on Postsecondary Teaching, Learning, and Assessment at Pennsylvania State University, 1992. p. 10-30. Disponível em: https://files.eric.ed.gov/fulltext/ED357705.pdf. Acesso em: 18 jun. 2020.

SOARES, K. R. B.; LIMA, S. de C. O uso do Duolingo no ensino de língua inglesa em curso técnico de nível médio integrado. LínguaTec, v. 4, n. 1, p. 158-170, jun. 2019. 
DOI: https://doi.org/10.35819/linguatec.v4.n1.a3462. Disponível em: https://periodicos.ifrs.edu.br/index.php/LinguaTec/article/view/3462. Acesso em: 20 jun. 2020.

STORCH, N. Collaborative writing: Product, process, and students' reflections. Journal of Second Language Writing, [s.1.], v. 14, n. 3, p.153-173, set. 2005. Elsevier BV. http://dx.doi.org/10.1016/j.jslw.2005.05.002. Disponível em: https://www.sciencedirect.com/science/article/abs/pii/S1060374305000172. Acesso em: 18 jun. 2020.

STROBL, C. Affordances of Web 2.0 Technologies for Collaborative Advanced Writing in a Foreign Language. Calico Journal, [s.1.], v. 31, n. 1, p. 1-18, 31, jan. 2014. Disponível em: https://journals.equinoxpub.com/CALICO/article/viewFile/22799/18823. Acesso em: 18 jun. 2020.

WANG, S.; VÁSQUEZ, C. Web 2.0 and second language learning: what does research tell us? Calico Journal, [s.1.], v. 29, n. 3, p. 412-430, ago. 2012. Disponível em: https://journals.equinoxpub.com/CALICO/article/view/23718. Acesso em: 16 jun. 2020.

YEH, H. Exploring how collaborative dialogues facilitate synchronous collaborative writing. Language Learning \& Technology, Hawaii, v. 18, n. 1, p. 23-37, fev. 2014. Disponível em: https://www.lltjournal.org//item/2834. Acesso em: 28 maio 2018.

YIM, S. et al. Synchronous writing in the classroom: undergraduates' collaborative practices and their impact on text quality, quantity, and style. In: ACM Conference, Portland-OR, p. 1-12, mar. 2017. Trabalho apresentado no $20^{\text {th }}$ ACM Conference on CSCW. DOI: 10.1145/2998181.2998356. Disponível em: https://www.researchgate.net/publication/313738684_Synchronous_Collaborative_Writi ng_in_the_Classroom_Undergraduates'_Collaboration_Practices_and_their_Impact_on_ Writing_Style_Quality_and_Quantity. Acesso em: 16 jun. 2020.

YIM, S.; WARSCHAUER, M. Web-based collaborative writing in L2 contexts: methodological insights from text mining. Language Learning \& Technology, Hawaii, v. 21, n. 1, p. 146-165, fev. 2017. Disponível em: https://www.lltjournal.org//item/2989. Acesso em: 28 maio 2018.

Recebido em 20 de junho de 2020

Aceito em 17 de julho de 2020 